\title{
Pengaruh Model Pembelajaran Predict, Observe And Explain terhadap Keterampilan Proses Sains Siswa Kelas X Sma Negeri 1 Balaesang
}

\author{
Zulaeha, I Wayan Darmadi dan Komang Werdhiana \\ e-mail: Zulaeha@yahoo.co.id \\ Program Studi Pendidikan Fisika, Jurusan Pendidikan MIPA, Universitas Tadulako \\ Jl. Soekarno Hatta KM. 9 Kampus Bumi Tadulako Tondo Palu - Sulawesi Tengah
}

\begin{abstract}
Abstrak - Penelitian ini bertujuan untuk mengetahui pengaruh model pembelajaran Predict, Observe and Explain (POE) keterampilan proses sains siswa pada materi kalor yang diajarkan dengan menggunakan model pembelajaran POE dengan pembelajaran konvensional. Jenis penelitian yang digunakan adalah kuasi eksperimen dengan desain The Non Equivalen Pretest-Posttest Design dengan menggunakan teknik purposive sampling diperoleh kelas $X_{A}$ sebagai kelas eksperimen dan kelas $X_{B}$ sebagai kelas kontrol. Instrumen yang digunakan berupa tes keterampilan proses sains dalam bentuk tes esai berjumlah 8 soal. Analisis data dilakukan dengan teknik statistik uji-t satu pihak untuk menguji perbedaan rerata skor keterampilan proses sains siswa dengan signifikansi $a=0,05$ dengan kriteria pengujian terima $\mathrm{H}_{0}$ jika thitung $<$ tabel untuk harga $\mathrm{t}$ lainya $\mathrm{H}_{0}$ ditolak. Berdasarkan hasil analisis data diperoleh nilai hasil thitung $=1,71>t_{\text {tabel }}=1,66$. Ini berarti bahwa nilai thitung berada di luar daerah penerimaan $\mathrm{H}_{0}$. Dengan demikian disimpulkan bahwa, terdapat pengaruh keterampilan proses sains antara kelas yang mendapatkan pembelajaran menggunakan model pembelajaran POE dengan kelas yang mendapatkan pembelajaran konvensional.
\end{abstract}

Kata Kunci: Model POE, Keterampilan proses sains

\section{PENDAHULUAN}

Suhu dan kalor merupakan salah satu konsep fisika yang sering kita jumpai dalam kehidupan sehari-hari. Pada konsep suhu dan kalor siswa dituntut untuk dapat mengamati perubahan suhu pada termometer, membuat hipotesis mengenai perpindahan kalor, menginterpretasi data antara suhu dan waktu yang menyebabkan perubahan wujud dan mengkomunikasikan grafik perubahan wujud tersebut. Peristiwa-peristiwa tersebut hanya dapat ditemukan dan diselidiki dengan menggunakan keterampilan proses siswa.

Pembelajaran yang melibatkan siswa melalui kegiatan eksperimen, selain siswa dapat mendengar penjelasan guru siswa juga dapat melihat dan mengalami fenomena yang sedang dipelajari. Benny [1] mengemukakan bahwa peristiwa belajar akan berlangsung lebih efektif jika siswa berhubungan langsung dengan objek yang sedang dipelajari dan ada di lingkungan sekitar. Pembelajaran menjadi bermakna bagi siswa jika guru bisa memberikan keterampilan-keterampilan tertentu dalam kegiatan pembelajaran fisika. Salah satu keterampilan dalam pembelajaran fisika adalah keterampilan proses sains (KPS).

Hasil observasi di SMA Negeri 1 Balaesang menunjukkan bahwa kegiatan pembelajaran fisika yang dilaksanakan belum bisa memfasilitasi siswa untuk mengembangkan keterampilan proses sainsya. Hal ini dikarenakan guru masih menggunakan metode ceramah dalam penyampaian materi pembelajaran. Dalam proses pembelajaran fisika masih cenderung berbasis hafalan teori, konsep-konsep dan rumus serta tidak didasarkan pada pengalaman siswa yang menyebabkan rendahnya keterampilan proses sains (KPS) siswa. Pengembangan KPS siswa 
tidak dapat diajarkan dengan menggunakan metode ceramah. Alasan guru masih menggunakan metode ceramah karena metode ini mudah untuk dilaksanakan baik dari segi persiapan, waktu dan peralatan dan guru beranggapan bahwa siswa hanya bisa mengerti bila dijelaskan secara panjang lebar. Selain itu, dalam kegiatan pembelajaran, aktifitas percobaan (eksperimen) dilaksanakan hanya pada tiap kenaikan kelas untuk keperluan nilai praktek dan itu hanya untuk siswa kelas XII.

Keterampilan proses sains (KPS) merupakan keterampilan yang harus dikembangkan pada siswa. Beberapa alasan mengapa KPS harus dimiliki oleh siswa yaitu (1) sains (khususnya fisika) terdiri dari tiga aspek yaitu produk, proses dan sikap. Dengan mengembangkan KPS siswa akan memahami bagaimana terbentuknya hukum, teori dan rumus yang sudah ada sebelumnya melalui percbaan; (2) sains (fisika) berubah seiring dengan perkembangan jaman. Oleh karena itu guru tidak mungkin lagi mengajarkan semua konsep dan fakta pada siswa dari sekian mata pelajaran. Siswa perlu dibekali keterampilan yang dapat membantu siswa menggali dan menemukan informasi dari berbagai sumber bukan dari guru saja; (3) siswa akan lebih memahami konsepkonsep yang rumit dan abstrak jika disertai dengan contoh-contoh yang konkrit; (4) Siswa akan memiliki pemahaman yang mendalam terhadap materi pelajaran dan mendorong siswa lebih aktif dalam pembelajaran.

Kinkin Suartini [2] menyatakan bahwa KPS meliputi keterampilan mengamati, mengelompokkan, menafsirkan, meramalkan, mengajukan

pertanyaan, mengajukan hipotesis, merencanakan percobaan, menggunakan alat/bahan/sumber, menerapkan konsep, melakukan komunikasi dan melaksanakan percobaan. Keterampilan tersebut dapat dikembangkan melalui kegiatan praktikum di sekolah. Oleh karena itu diperlukan adanya suatu pembelajaran yang mampu meningkatkan kemampuan kognitif sekaligus mengembangkan keterampilan proses sains siswa.

Salah satu model pembelajaran yang mampu mengembangkan keterampilan proses sains siswa secara optimal adalah model pembelajaran Predict, Observe and Explain (POE). Menurut Restami [3] model pembelajaran POE dapat mencakup cara-cara yang dapat ditempuh oleh seorang guru untuk membantu siswa dalam meningkatkan pemahaman konsepnya, maupun psikomotor. Model pembelajaran POE melibatkan siswa dalam meramalkan suatu fenomena, melakukan observasi melalui demonstrasi atau eksperimen, dan akhirnya menjelaskan hasil demonstrasi serta ramalan mereka sebelumnya. Dengan melakukan cara seperti ini pengetahuan yang diperoleh siswa akan melekat dalam ingatannya dan keterampilan proses sains siswa meningkat.

Model pembelajaran POE menghadirkan suatu keadaan konkret dari suatu konsep pengetahuan. Seperti yang dikemukakan oleh Rustaman [3] bahwa dalam proses pembelajaran fisika kemampuan observasi sangat mendasar untuk melakukan eksplorasi terhadap fenomena-fenomena dan untuk menguji gagasan dengan melibatkan semua indera. 
Dalam penelitian ini keterampilan proses sain yang diteliti meliputi ketrampilan memprediksi, mengamati, mengkomunikasikan dan menginterpretasi. Keterampilan memprediksi, mengamati dan mengkomunikasikan terdapat dalam lingkup model pembelajaran POE. Melalui penelitian ini siswa diharapkan dapat mengajukan fenomena yang akan terjadi pada pengamatan, menemukan dan mengumpulkan fakta yag terjadi pada pengamatan, menjelaskan hasil percobaan dan membuat grafik serta membaca grafik dan menyimpulkan hasil percobaan dan menghubungkan hasil pengamatan tersebut.

Berdasarkan uraian yang dijelaskan diatas, penelitian ini mengkaji "pengaruh model pembelajaran Predict, Observe and Explain (POE) terhadap keterampilan proses sains siswa SMA Negeri 1 Balaesang.

\section{METODOLOGI PENELITIAN}

1) Jenis dan Design Penelitian

Penelitian ini menggunakan metode kuasi eksperimen, dengan desain penelitian adalah "The Non Equivalen Pretest-Posttest Design". Desain ini menggunakan kelas-kelas yang sudah ada sebagai kelompoknya, dengan memilih kelas-kelas yang diperkirakan sama keadaan/kondisinya. Penarikan sampel dilakukan dengan menggunakan tekhnik purposive sampling atau penentuan sampel berdasarkan tujuan penelitian. Diperoleh jumlah sampel kelas eksperimen 40 siswa dan kelas kontrol 40 siswa. Bentuk desainnya disajikan pada Tabel 1.
Tabel 1 Desain Penelitian The Non Ekuivalen PretestPostest Design

\begin{tabular}{|c|c|c|c|}
\hline Group & $\begin{array}{c}\text { Tes } \\
\text { Awal }\end{array}$ & $\begin{array}{c}\text { Variabel } \\
\text { Terikat }\end{array}$ & $\begin{array}{c}\text { Tes } \\
\text { Akhir }\end{array}$ \\
\hline $\begin{array}{c}\text { Kelas } \\
\text { Eksperimen } \\
\left(\mathrm{X}_{\mathrm{A}}\right)\end{array}$ & $\mathrm{O}$ & $\mathrm{X}_{1}$ & $\mathrm{O}$ \\
\hline $\begin{array}{c}\text { Kelas Kontrol } \\
\left(\mathrm{X}_{\mathrm{B}}\right)\end{array}$ & $\mathrm{O}$ & $\mathrm{X}_{2}$ & $\mathrm{O}$ \\
\hline
\end{tabular}

[5]

Keterangan :

$\mathrm{X}_{1}$ : keterampilan proses sains untuk kelas yang diberi pembelajaran model POE

$\mathrm{X}_{2}$ : keterampilan prose sains untuk kelas yang diberi pembelajaran metode ceramah

0: Tes awal atau Tes Akhir

2) Lokasi dan waktu penelitian Penelitian ini dilaksanakan di SMA Negeri 1 Balaesang. Penelitian dilaksanakan mulai tanggal 25 Februari - 26 Maret 2014.

3) Tehnik Analisis Data

(1) Pengujian Normalitas Data Untuk pengujian normalitas data, digunakan rumus Chi-kuadrat yaitu seperti pada persamaan berikut

$$
\chi_{\text {hitung }}^{2}=\sum_{i=1}^{k} \frac{\left(O_{i}-E_{i}\right)^{2}}{E_{i}}
$$

$X^{2}$ hitung : Uji normalits Chi-kuadrat

k : interval kelompok

$\mathrm{O}_{\mathrm{i}} \quad$ :frekwensi pengamatan

$\mathrm{E}_{1} \quad$ :frekwensi yang diharapkan

Kriteria pengujian yang digunakan digunakan pada $\mathrm{dk}=(\mathrm{k}-3)$ dan peluang $(1-\mathrm{a})$ dengan taraf nyata $a=0,05$ adalah jika $X^{2}$ hitung $<X^{2}$ tabel, maka data dilakatakan berasal dari populasi yang berdistribusi normal.

(2) Uji Homogenitas Varians 
Uji homogenitas varians digunakan untuk mengetahui apakah varian antara kelompok data homogen. Uji ini didasarkan pada uji statistik Uji Fisher (Uji F) seperti tertera pada persamaan berikut

$$
F=\frac{S_{1}^{2}}{S_{2}^{2}}
$$

Keterangan :

F : nilai $F$ hitung

$S_{1}^{2}:$ varians terbesar

$S_{2}{ }^{2}$ : varians terkecil

Jika $F_{\text {hitung }}>F_{\text {tabel }}$, maka data berasal dari populasi yang tidak homogen. Jika $F_{\text {hitung }}<F_{\text {tabel }}$ maka data berasal dari populasi yang homogen

(3) Uji Peningkatan Keterampilan Proses Sains

Untuk mengetahui peningkatan keterampilan proses sains siswa yang diperoleh pada kelas eksperimen yang menggunakan model pembelajaran POE dihitung berdasarkan skor $\mathrm{N}$-gain. Untuk memperoleh skor $\mathrm{N}$-gain digunakan persamaan

$$
\mathrm{g}=\frac{S_{\text {post }}-S_{\text {pre }}}{S_{\text {maks }}-S_{\text {pre }}} \times 100
$$

Dengan:

Spost : Skor tes akhir

Spre : Skor tes awal

Smaks : skor maksimum

Tabel 2 Kriteria Skor N-Gain

\begin{tabular}{|c|c|}
\hline Skor N-Gain & Kriteria \\
\hline $\mathrm{g}<30$ & Rendah \\
$30 \leq \mathrm{g} \geq 70$ & Sedang \\
$\mathrm{G}>70$ & Tinggi \\
\hline
\end{tabular}

(4) Uji Hipotesis

Untuk mengetahui seberapa jauh hipotesis yang telah dirumuskan didukung oleh data yang dikumpulkan, maka hipotesis tersebut harus diuji. Jika sebaran data berdistribusi normal dan homogen, maka data yang diperoleh dianalisis dengan menggunakan uji statistik parametrik ( $u j i$ " $t$ ") dengan pasangan hipotesis adalah:

$\mathrm{H}_{0}: \mu_{1}=\mu_{2}$ : Tidak ada perbedaan ratarata skor KPS antara kelas yang mendapat model pembelajaran POE dengan kelas yang mendapat pembelajaran konvensional

$\mathrm{H}_{1}: \mu_{1}>\mu_{2}$ : Ada perbedaan rata-rata skor KPS antara kelas yang mendapat model pembelajaran POE dengan kelas yang mendapat pembelajaran konvensional.

Rumus yang digunakan untuk uji kesamaan dua rata-rata dari dua sampel bebas seperti tertera pada persamaan berikut

$$
t_{\text {hit }}=\frac{\overline{x_{1}}-\overline{x_{2}}}{S \sqrt{\frac{1}{n_{1}}+\frac{1}{n_{2}}}}
$$

Dimana:

$$
S=\sqrt{\frac{\left(n_{1}-1\right) S_{1}^{2}+\left(n_{2}-1\right) S_{2}^{2}}{n_{1}+n_{2}-2}}
$$

\section{Dengan:}

$\mathrm{X}_{1}$ : : skor rata-rata kelompok eksperimen

$\mathrm{X}_{2}$ : skor rata-rata kelompok kontrol

$\mathrm{n}_{1} \quad$ : jumlah siswa kelompok eksperimen

$\mathrm{n}_{2} \quad$ : jumlah siswa kelompok kontrol

S : simpangan baku (standar deviasi)

Dengan kriteria pengujian yakni terima $\mathrm{H}_{0}$ jika thitung $<$ tabel pada taraf nyata 0,05 dan $\mathrm{dk}=\left(\mathrm{n}_{1}+\mathrm{n}_{2}-2\right)$ serta untuk harga $t$ lainnya $\mathrm{H}_{0}$ di tolak. Namun, jika sebaran data yang diperoleh tidak normal dan homogen maka digunakan uji statistik non-parametrik. 


\section{HASIL DAN PEMBAHASAN}

1) Data Hasil Tes Awal dan Tes Akhir

Adapun data hasil Pretest dan Posstest disajikan pada Gambar 1.

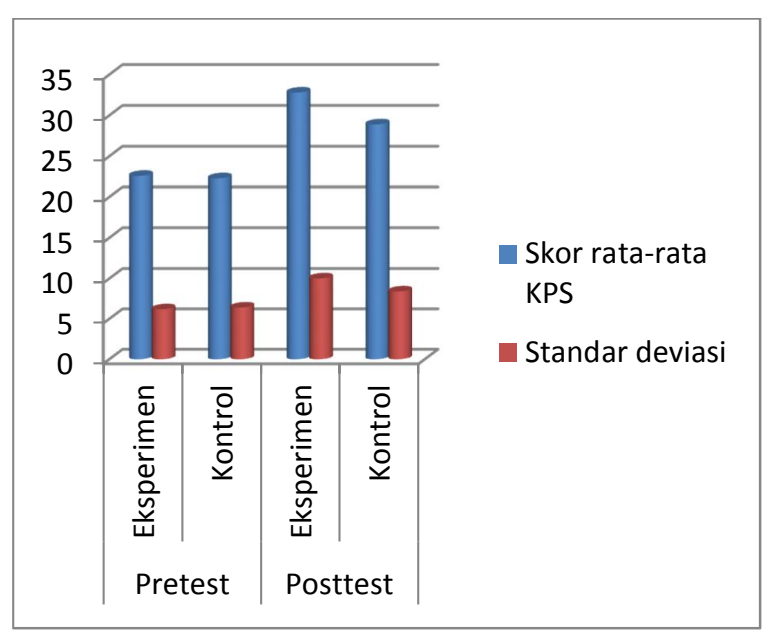

Gambar 1 Grafik Skor Tes Keterampilan Proses Sains

\section{2) Uji Normalitas}

Uji normalitas pada penelitian ini menggunakan uji Chi-kuadrat dengan kriteria penerimaan $X^{2}$ Hitung $<X^{2}$ tabel, taraf signifikansi a $=0,05$ dan derajat kebebasan $\mathrm{dk}=\mathrm{k}-3$. Data hasil perhitungan disajikan pada Tabel 3dan 4 berikut

Tabel 3 Hasil Uji Normalitas Pretest

\begin{tabular}{|c|c|c|c|c|}
\hline No. & Kelas & $\begin{array}{l}\text { Nilai } \\
X^{2} \text { Hitung }\end{array}$ & \begin{tabular}{l}
\multicolumn{1}{c}{ Nilai } \\
$\mathrm{X}^{2}$ Tabel \\
$(\mathrm{a}=0,05)$
\end{tabular} & Keputusan \\
\hline 1 & $\begin{array}{c}\text { Kelas } \\
\text { eksperimen }\end{array}$ & 0,51 & \multirow{2}{*}{7,81} & $\begin{array}{c}\text { Terdistribusi } \\
\text { normal }\end{array}$ \\
\hline 2 & $\begin{array}{c}\text { Kelas } \\
\text { kontrol }\end{array}$ & 1,37 & & $\begin{array}{c}\text { Terdistribusi } \\
\text { normal }\end{array}$ \\
\hline
\end{tabular}
Tabel 4 Hasil Uji Normalitas Posstest

\begin{tabular}{|c|c|c|c|c|}
\hline No. & Kelas & $\begin{array}{c}\text { Nilai } \\
X^{2} \text { Hitung }\end{array}$ & $\begin{array}{c}\text { Nilai } \\
X^{2} \text { Tabel } \\
(\mathrm{a}=0,05)\end{array}$ & Keputusan \\
\hline 2 & $\begin{array}{c}\text { Kelas } \\
\text { eksperimen }\end{array}$ & 0,48 & & $\begin{array}{c}\text { Terdistribusi } \\
\text { normal }\end{array}$ \\
\cline { 2 - 3 } & $\begin{array}{c}\text { Kelas } \\
\text { kontrol }\end{array}$ & 1,06 & $\begin{array}{c}\text { Terdistribusi } \\
\text { normal }\end{array}$ \\
\hline
\end{tabular}

Sesuai kriteria pengambilan keputusan maka baik data dari kelas eksperimen maupun kelas kontrol keduanya berasal dari populasi yang terdistribusi normal.

3) Uji Homogenitas

Uji homogenitas pada penelitian ini menggunakan uji statistik $F$ dengan taraf signifikansi $\mathrm{a}=0,05$ dan nilai varians kelas eksperimen sebesar 32,16 serta kelas kontrol sebesar 45,11. Berdasarkan hasil perhitungan, diperoleh nilai $F_{\text {hitung }}$ sebesar 1,40. Data untuk pengujian homogenitas dapat dilihat pada Tabel 5 dan 6 berikut

Tabel 5 Hasil Uji Homogenitas Tes Awal

\begin{tabular}{|c|c|c|l|}
\hline Kelas & F & Fitung & Keputusan \\
\cline { 1 - 4 } Eksperimen & 1.02 & 1,80 & $\begin{array}{l}\text { Kedua Data } \\
\text { Homogen }\end{array}$ \\
\hline Kontrol & & 1.02 & \\
\hline
\end{tabular}

Tabel 6 Hasil Uji Homogenitas Tes Akhir

\begin{tabular}{|c|c|c|c|}
\hline Kelas & $F_{\text {hitung }}$ & $F_{\text {tabel }}$ & Keputusan \\
\hline Eksperimen & \multirow{2}{*}{1,42} & \multirow{2}{*}{1,69} & \multirow{2}{*}{$\begin{array}{c}\text { Kedua Data } \\
\text { Homogen }\end{array}$} \\
\hline Kontrol & & & \\
\hline
\end{tabular}

Dari Tabel 5 dan 6 dapat dilihat bahwa nilai Fhitung berada pada daerah penerimaan $\mathrm{H}_{0}$ dengan demikian data tersebut menujukan kedua kelas yang dijadika sampel berasal dari populasi yang homogen.

4) Uji Peningkatan Keterampilan Proses

Sains

Peningkatan keterampilan proses sains siswa yang diperoleh pada kelas eksperimen yang menggunakan model pembelajaran POE yang dihitung menggunakan persamaan $\mathrm{N}$ Gain dapat dilihat pada Tabel 7

Tabel 7 Hasil Uji Peningkatan Keterampilan Proses Sains

\begin{tabular}{|l|c|c|c|}
\hline \multicolumn{1}{|c|}{ Uraian } & Pretest & Posstest & N-Gain \\
\hline Sampel & 40 & 40 & 40 \\
\hline Nilai Terendah & 12 & 18 & 2,56 \\
\hline Nilai Tertinggi & 36 & 53 & 79,49 \\
\hline Nilai Rata-rata & 22,6 & 32,8 & 28,29 \\
\hline
\end{tabular}

Berdasarkan hasil uji N-Gain pada Tabel 7 diperoleh nilai 28,29 dengan kriteria skor $\mathrm{N}$ Gain, < 30. Disimpulkan bahwa peningkatan KPS rendah. Dengan kata lain, pembelajaran POE yang diterapkan tidak mempengaruhi KPS siswa secara signifikan.

5) Uji Hipotesis 
Berdasarkan data yang diperoleh dari skor tes awal dan tes akhir dari kelas kontrol dan kelas eksperimen, maka dilakukan uji beda dua rata-rata (satu pihak) pada taraf nyata a $=0,05$ dan $\mathrm{dk}=\left(\mathrm{n}_{1}+\mathrm{n}_{2}-2\right)=40+40-2$. Data hasil perhitungan tersebut disajikan dalam Tabel 8 dan 9.

Tabel 8 Uji Hipotesis (Tes Awal)

\begin{tabular}{|l|l|l|l|l|}
\hline Kelas & Nilai $\bar{x}$ & thitung & tabel & Keputusan \\
\hline $\begin{array}{l}\text { Kelas } \\
\text { Eksperimen }\end{array}$ & 22,6 & & & \\
\cline { 1 - 2 } $\begin{array}{l}\text { Kelas } \\
\text { Kontrol }\end{array}$ & 22,3 & 0,32 & 1,66 & $\begin{array}{c}\mathrm{H}_{0} \\
\text { Diterima }\end{array}$ \\
\hline
\end{tabular}

Berdasarkan data Tabel 8 dengan diperoleh $t_{0,95(78)}=1,66$. Berdasarkan hasil perhitungan diketahui thitung $0,32<$ tabel 1,66 , nilai thitung berada pada daerah penerimaan $\mathrm{H}_{0}$. Diperoleh bahwa tidak ada perbedaan keterampilan proses sains antara kelas yang mendapatkan pembelajaran menggunakan pembelajaran POE dengan kelas yang mendapatkan pembelajaaran konvensional. Artinya sebelum diberi perlakuan, kemampuan awal keterampilan proses sains siswa pada kelas eksperimen dan kelas kontrol tidak berbeda secara signifikan.

Tabel 9 Uji Hipotesis (Tes Akhir)

\begin{tabular}{|l|l|l|l|c|}
\hline Kelas & Nilai $\overline{\mathrm{X}}$ & thitung & tabel & Keputusan \\
\hline $\begin{array}{l}\text { Kelas } \\
\text { Eksperimen }\end{array}$ & 32,8 & \multirow{2}{*}{1,71} & 1,66 & $\begin{array}{c}\mathrm{H}_{1} \\
\text { Diterima }\end{array}$ \\
\cline { 1 - 2 } $\begin{array}{l}\text { Kelas } \\
\text { Kontrol }\end{array}$ & 28,9 & & \\
\hline
\end{tabular}

Berdasarkan data Tabel 9 diketahui thitung $=1,71>t_{\text {tabel }}=1,66$. Dengan demikian, $H_{0}$ ditolak dan $\mathrm{H}_{1}$ diterima. Disimpulkan bahwa ada perbedaan keterampilan proses sains antara kelas yang mendapatkan pembelajaran menggunakan pembelajaran POE dengan kelas yang mendapatkan pembelajaran konvensional. Artinya model pembelajaran POE mempengaruhi KPS siswa.
Tujuan penelitian ini adalah untuk menguji pengaruh model pembelajaran POE terhadap keterampilan proses sains siswa SMA Negeri 1 Balaesang pada materi kalor Berdasarkan hasil analisis skor rata-rata KPS tes awal siswa yang ditunjukan pada Gambar 1 diketahui bahwa skor rata-rata KPS siswa pada kelas eksperimen dan kelas kontrol tidak berbeda jauh. Skor rata-rata kelas eksperimen adalah 22,6 dan kelas kontrol adalah 22,3. Sementara, berdasarkan analisis uji-t diperoleh bahwa sebelum diberi perlakuan dalam proses pembelajaran, tidak ada perbedaan KPS antara kedua kelas tersebut. Hal ini menunjukan bahwa kemampuan awal siswa dalam keterampilan proses sains pada kedua kelas ini tidak berbeda.

Setelah kedua kelas ini diberi perlakuan yang berbeda yakni pada kelas eksperimen dilakukan pembelajaran POE dan untuk kelas kontrol dilakukan pembelajaran konvensional. Hasil analisis tes akhir menunjukan bahwa perolehan skor rata-rata KPS siswa pada kelas eksperimen dan kelas kontrol berbeda. Skor rata-rata KPS siswa kelas eksperimen adalah 32,8 dan kelas kontrol adalah 28,9. KPS siswa yang diberi pembelajaran POE lebih tinggi dari siswa yang diberi pembelajaran konvensional. Berdasarkan analisis uji-t diperoleh bahwa setelah diberi pembelajaran POE ada perbedaan KPS kedua kelas tersebut. Hal ini menunjukkan bahwa pada materi kalor, proses pembelajaran di kelas yang dilakukan dengan pembelajaran POE akan mempengaruhi KPS siswa dibanding proses pembelajaran konvensional walaupun peningkatan KPS-nya rendah. Hal ini dikarenakan pada kelas dengan pembelajaran 
POE, memberikan kesempatan kepada siswa untuk dapat mengobservasi secara langsung melalui kegiatan eksperimen terhadap materi yang sedang dipelajari sehingga siswa dapat berpartisipasi secara aktif dan siswa lebih paham terhadap materi kalor.

Peningkatan KPS siswa dalam pembelajaran disebabkan pembelajaran POE merupakan pembelajaran yang dapat memberikan pengetahuan baru kepada siswa secara nyata serta dapat meningkatkan partisipasi siswa agar lebih aktif dan kreatif dalam pembelajaran. Metode eksperimen yang digunakan dalam pembelajaran POE melatih siswa mencari dan menemukan sendiri berbagai jawaban atau persoalan yang dihadapinya.

Dengan metode eksperimen pada materi kalor siswa dituntut untuk dapat mengamati perubahan suhu pada termometer, membuat hipotesis mengenai perpindahan kalor, menginterpretasi data antara suhu dan waktu yang menyebabkan perubahan wujud dan mengkomunikasikan grafik perubahan wujud tersebut. Fenomena ini hanya dapat ditemukan dan diselidiki dengan menggunakan keterampilan proses sains. Penerapan pembelajaran POE yang tahapanya terdiri dari predict, observe and explain dapat membantu siswa dalam mencapai KPS. Metode eksperimen yang digunakan dalam pembelajaran POE sangat membantu siswa dalam mengamati fenomena fisika yang ada dalam materi kalor.

Model pembelajaran POE dalam proses pembelajaran dapat meningkatkan KPS siswa, hal ini sejalan dengan penelitian yang dilakukan oleh Herni Budiati [7] yang menyatakan bahwa pembelajaran POE dengan prosedur metode eksperimen yang dilaksanakan selam proses pembelajaran berlangsung mampu mengakomodasi siswa dalam memperoleh KPS baik dalam aspek kognitif, afektif maupun psikomotor. Dari segi penguasaan konsep dan sikap ilmiah yang diteliti oleh Restami (2013) diketahui bahwa pembelajaran POE dapat meningkatkan penguasaan konsep fisika dan kerja ilmiah siswa.

Berdasarkan hasil perhitung uji N-Gain kelas eksperimen nilai pretest dan posstest pada Tabel 7 diperoleh nilai N-Gain sebesar 28,29 yang berarti terdapat peningkatan keterampilan proses sains siswa. Namun peningkatan KPS siswa dalam katergori rendah. Hal ini dipengaruhi beberapa faktor pada saat menerapkan pembelajaran model POE yaitu pada pertemuan pertama sebagaian siswa terlihat malas untuk ikut terlibat dalam kegiatan eksperimen meskipun sebagian siswa lain mengaku senang dengan kegiatan eksperimen seperti ini. Pada saat diskusi banyak siswa terlihat malu untuk terlibat menyampaikan pendapat dalam diskusi, sebagian siswa terlihat lebih senang dengan gaya belajar guru yang menerangkan materi pembelajaran. Jumlah siswa dalam kelas terlalu banyak yaitu 40 orang sehingga guru kesulitan mengorganisir kelas pada saat melakukan eksperimen. Untuk melihat pengaruh metode dalam pembelajaran harusnya pertemuan tatap muka diperbayak, namun pada penelitian ini tatap muka hanya tiga kali pertemuan.

Model pembelajaran POE membutuhkan sebuah observasi yang nyata untuk 
membuktikan dugaan siswa. Metode eksperimen yang digunakan dalam pembelajaran POE memilki kelebihan siswa lebih aktif dan terampil dalam melakukan eksperimen, namun membutuhkan waktu yang cukup lama dan jumlah siswa yang tidak terlalu banyak. Dalam pembelajaran dengan metode ceramah guru dapat lebih mudah mengontrol kelas meskipun dalam jumlah siswa yang banyak. Selain itu kebanyakan siswa ini lebih senang dengan gaya belajar yang mengandalkan penjelasan dari guru. Hal ini menunjukan bahwa pembelajaran POE yang diterapkan pada kelas eksperimen tidak mempengaruhi KPS siswa secara signifikan.

\section{KESIMPULAN}

Berdasarkan hasil analisis disimpulkan bahwa terdapat pengaruh keterampilan proses sains siswa antara kelas yang mendapatkan model pembelajaran POE dengan kelas yang mendapatkan pembelajaran menggunakan metode konvensional SMA Negeri 1 Balaesang. Diperoleh bahwa peningkatan KPS siswa rendah atau tidak berpengaruh secara signifikan.

\section{PUSTAKA RUJUKAN}

[1] Pribadi, A Benny. (2009). Model Desain Sistem Pembelajaran. Jakarta: Dian Rakyat.
[2] Suartini, Kinkin. (2007). Pendekatan Dalam proses pembelajaran Matematika dan Sains Dasar. Jakarta: IAIN Indonesia Social Equity Project

[3] Restami, M.P. (2013). Pengaruh Model pembelajaran POE (Predikct, Observe, and Explain Terhadap Pemahaman Konsep Fisika dan Sikap IImiah di Tinjau dari gaya Belajar Siswa. Dalam e-Journal Program Pasca Sarjana universitas Pendidikan Ganesha Program Studi IPA [Online], Vol 3, 10 halaman. Tersedia: http://www.pasca.undiksha.ac.id. [18 Juli 2013].

[5] Sudjana. (2005). Metode Statistik edisi 6. Bandung: Tarsito

[6] Sugiyono. (2010). Metode Penelitian Pendidikan (Pendekatan Kuantitatif, Kualitatif dan R\&D. Bandung: Alfabeta.

[7] Budiati, Herni. (2012). Pengaruh Model Pembelajaran POE (Predict, Observe and Explain) Menggunakan Metode Eksperimen Sederhana dan Eksperimen Terkontrol Ditinjau dari Keterampilan Metakofnitif dan Gaya Belajar Terhadap Keterampilan Proses Sains. [Online]. Tersedia:http://www.Jurnal.fkip.uns.ac.id. [28 April 2014]. 